\title{
The Relation of Peer Group with the Self-Concept of Teenagers on Sexual Behavior
}

\author{
Delfriana Ayu A ${ }^{1}$, Dinda Aljarina ${ }^{2}$, Prodalima Sinulingga ${ }^{3}$ \\ ${ }^{1}$ Lecturer in Faculty Of Public Health University of Islamic State Sumatera Utara, Indonesia \\ delfriana@yahoo.com \\ ${ }^{2}$ Graduated Faculty Of Public Health University of Sumatera Utara, Indonesia \\ dinda.pelawi@gmail.com \\ ${ }^{3}$ Lecturer in STIKes Nurul Hasanah Kutacane Aceh Tenggara, Indonesia \\ prodalima@gmail.com
}

\begin{abstract}
Unhealthy sexual behavior among the teenagers, especially in those who are still single, tends to be increasing. Selfconcept has influence on the behavior of the teenagers in which the teenagers will behave in accordance with the self-concept they own. The factor that can influence the forming of the teenagers' self-concept on the sexual behavior is peer group. The purpose of this quantitative study with cross-sexual approach was to find out the influence of peer group on the self-concept of the teenagers on sexual behavior at SMA Dharma Bakti Medan. The population of this study was allmof the 90 students of Class $X$ and XI and all of them were selected to be the samples for this stufy. The data for this study were obtained through questionnaire distribution. The data obtained were analyzed through multiple linear regression test at $\alpha=0.05$. The result of this study showed that $72.2 \%$ of the teenagers had good self-concept on sexual behavior and $27.8 \%$ had poor self-concept on sexual behavior. Peer group in strong category was $60.0 \%$ and in weak category was $40.0 \%$ and there was a significant relationship between and positive influence on the self-concept of the teenagers on sexual behavior. With Adjusted $R$ square $=\mathbf{0 . 4 4 0}, \mathrm{t}$ means that $\mathbf{4 4 . 0 \%}$ of the teenagers self-concept on sexual behavior can be explained by the variabls of peer group. While the remaining $54.0 \%$ can be explained by the other causes that were not included in this study. The management of the school is suggested to instill more discipline to generate attitude and disciplined behavior in the students that they can be prevented from any behavior which is not in accordance with the norms practiced in the society.
\end{abstract}

Keywords- Peer Group, Self-Concept, Sexual Behavior, Teenagers, Student

\section{I.INTRODUCTION}

Teenage is a period in which the changes both the changes that happened to him or due to environmental changes such as changes in the intellectual, emotional changes, changes in moral and changes that can be directly observed physical changes. In line with the changes that occur in Teenage, they are also faced with the tasks of different tasks on childhood. As known, in every phase of development, including in adolescence, the individual has a developmental tasks that must be met [12].

The number of adolescents aged 10-24 years based on the Census from Statistics in BKKBN (2013) in 2010 , about 64 million or $27.6 \%$ of the total population of 237.6 million people [7].

Adolescence is the period of the rapid growth and development of physical, psychological and intellectual. The pattern of rapid growth characteristics have led to teenagers wherever they live, have the same characteristics that have a great curiosity, love adventure and challenges as well as tend to dare to bear the risk of his actions without preceded by careful consideration. Properties are faced with the availability of facilities in the vicinity that can satisfy the curiosity. This situation often brings inner conflict within him. If the decision taken in the face of conflict is not right they will fall into risky behavior and may have to bear as a result of continued in the form of a variety of physical and psychosocial health problems, which may even have to bear all his life [7].

Every decision taken adolescents is a reflection of the adolescent self-concept. The self-concept has a considerable influence on the behavior of adolescents, the teenagers will behave in accordance with the concept of self-owned. Many conditions in the lives of teenagers who helped shape the personality pattern through its influence on the concept of self as physical and psychological changes in adolescence. The self-concept is the core of the personality pattern or picture that people have about themselves [9]. Another definition raised by Mead is to explain the views, judgments, and 
feelings of the individual about himself that arise as a result of a social interaction as a concept of self [4].

In adolescence, an individual will experience a situation in which puberty will undergo striking changes physically and emotionally / psychologically. Psychologically adolescence is a time of preparation and determined to enter the next stage of personality development, which becomes an adult. Maturity biological adolescent rural women are usually followed by the marriage of a young age that leads teenagers on the risks of pregnancy and childbirth, while the maturity of biological adolescent boys and girls in urban overshadowed more likely its early first age are sexually active, unwanted pregnancy, unsafe abortion, reproductive tract infections, including sexually transmitted diseases, and as a result of disability experienced [12]. World Health Organization (WHO) says the youth group, ie the population in the age range 1019 years, in Indonesia has approximately $1 / 5$ of the proportion of the total population [7]. This is in accordance with the proportion of teenagers in the world where the number of teenagers estimated 1.2 billion, or about $1 / 5$ of the world population.

Adolescents and the problem becomes an important issue today. Amount, around 64 million or $27.6 \%$ of the total Indonesian population (Census 2010) resulted in adolescent requires great care in its development. Besides, adolescents are highly vulnerable to the risk Triad Adolescent Reproductive Health (Sexuality, drugs, HIV and AIDS). Attitude unhealthy sexual among adolescents, particularly unmarried adolescents tend to increase. Data from the Ministry of Health in 2009 showed that $35.9 \%$ of adolescents in the four major cities (Medan, Jakarta, Bandung, and Surabaya) have a friend who had never had sex before marriage, and $6.9 \%$ of the respondents had had sex before marriage [1].

Teens Indonesia with the number reaching 42.2 million or approximately $20 \%$ of the population got a lot of obstacles or problems that usually appears in the form of risky behavior on his health. Risk behaviors that influence adolescent health issues include growth (change of physical and psychosocial), nutrition, abuse of Narcotics, Psychotropic and Other Addictive Substances (drug), and reproductive health, including sexually transmitted infections (STIs) / Infections Reproductive Tract (ISR) and Human Immunodeficiency Virus (HIV) / Acquired Immune Deficiency Syndrome (AIDS) [7].

Adolescence is a developmental transition between childhood and adulthood that includes changes in the physical, cognitive and social changes [20]. The development was studied and was influenced strongly by lingkungan. States that the behavior, environment and personal / cognition is an important factor in the development of teenage [7]. That influence factor adolescent behavior including the factor of parental family. Teenagers relation, have an influence directly and indirectly with premarital sexual behavior study conducted teenage. The better the relationship between parents with teenage children, the lower the adolescent premarital sexual behavior [11]. That influence factors adolescent premarital sexual behavior in the highest is the relationship between parents and teens, peer pressure, level understanding of religion (religiosity), and exposure of pornographic media [18].

Population Demographic Survey Indonesia (IDHS, 2012), shows that youth prefers to tell the matter to peers (71\%), and for parents (31\%) [2], [3]

Concluded that the variables of sex, puberty, knowledge, attitudes, marital status of parents, parenting parents, the number of boyfriends, old girlfriends and meetings with exposure to electronic media and print media significantly associated with adolescent sexual behavior [16]. On multivariate analysis, it was found that gender, knowledge, parenting parents and boyfriend number ever owned jointly affect sexual behavior.

The analysis showed that factors associated with high school students' attitudes toward sexual relations are emotional intelligence, knowledge of reproductive health, the role of parents and peers, the role of the mass media [6]. There are several determining factors of self-concept is a factor of parents, peers and society [17].

The self-concept is not innate, but rather the result of learning. Since humans know the environment, since it is also he learned many things about life. Based on the experience of his life, a person will establish the concept itself is based on various 
factors. Those factors are the shape of the body, disability, clothing, names and nicknames, intelligence intelligence, level of aspiration / aspiration, emotion, type / prestige of the school, social status, economic family, friends, and character / influential person. when various factors that tend to lead to positive feelings (pride, happy), then comes the positive self-concept [9].

Peer group as an individual interactions in children or adolescents with same age level and involve relatively large familiarity among the group.

A preliminary survey conducted in SMA Dharma Bakti Terrain some students rode home from school when he put a hand on your partner when riding a motorbike with his girlfriend. Interviews with several high school students Medan Dharma Bakti obtained, teens tend to assume normal sexual behavior lightweight (estimate, go on a date, holding hands, hugging, kissing her forehead and cheeks) in adolescents now. The students said that the mild sexual behavior may be done as long as both parties are happy to do so, there is no compulsion to do and mild sexual behavior is no longer taboo to be done by teenagers. They assume that love and sex are two things that are closely related, when love for someone to be peppered with sex, and sex is done with boyfriend must be grounded in love. The students are also recognized there were once together, there is currently dating, and some are already doing sexual behavior of light (estimate, going on dates, holding hands, kissing light (forehead and cheeks) and embracing each other. Some students interviewed also said no one has done the heavy sexual behaviors such as kissing lips.

\section{II.PROBLEMS}

Based on the description above, the problem of this research is that the peer group associated to the self concept of adolescents about sexual behavior in high school Dharma Bakti Medan in 2014 ".

The purpose of this study was to know the relation of peer group with self-concept of adolescents about sexual behavior in high school Dharma Bakti Medan.

\section{III.RESEARCH METHODS}

This research type is analytic with cross sectional design, in which all variables in this study were measured one at the same time [15], with the aim to determine the relations of the peer group with the self concept of teenagers about sexual behavior in high school Dharma Bakti Medan.

The population in this study were students of class $\mathrm{X}$ and class XI, the SMA Dharma Bakti as much as 90 people. Sampel in this study is the entire population of 90 people.

The analysis in this study include some analysis:

1. A univariate analysis was conducted to determine descriptive variables studied in the frequency distribution table to determine the characteristics and distribution data.

2. The bivariate analysis was conducted to determine the effect of the relationship of each independent variable with the dependent variable. The statistical test used is multiple linear regression.

\section{IV.RESULTS AND DISCUSSION}

\section{A. Self-Concept Teens About Sexual Behavior}

More than half of respondents $(75.6 \%)$ who agreed with dating is something natural, and almost half of respondents $(45.6 \%)$ strongly agree that sex is done after the official marriage. Furthermore, nearly half of respondents $(45.6 \%)$ strongly agree that a teenager should be more open and willing to talk about anything to the parents, as well as parents should further improve the monitoring of the association approached her teenage son found almost half of respondents $(41,1 \%)$ answered strongly agreed to the statement and changing partners in sex outside of marriage is very risky obtained $47.8 \%$ of respondents who strongly agree. Then also found $24.4 \%$ of respondents agree with the likes of pornographic images can make teens more mature, as well as statements pregnant outside of marriage is commonplace $18.9 \%$ repsonden agree. There are $25.6 \%$ of respondents agreed that the relationship did not kiss cool, $15.6 \%$ of respondents agreed anyway if pornographic movies are very interesting to watch and $21.1 \%$ of respondents agree that sex may be done by teenagers as a sincere expression of love to a girlfriend. 


\section{B. Peer Group}

Based on the results of a study of 90 students / $\mathrm{i}$ adolescent SMA Dharma Bakti Medan known that peer group significantly related to adolescent selfconcept with a $\mathrm{p}$ value of $0.000(\mathrm{p}<0.05)$.

From table 1 unknown 10 statements about the peer group and explained that half of the respondents $(73.3 \%)$ closer to friends than with a gang of friends who are not one gang, but half of the respondents $(62.2 \%)$ say that it is not must have a boyfriend to be a member of a gang. Furthermore, there are 52.2\% of respondents answered often talk about sex when gathered with friends and there are $58.9 \%$ of respondents said taught how to date by his friends. Later it was found $41.1 \%$ of respondents said invited to watch porn together with friends and half of the respondents $(57.8 \%)$ answered hugging and kissing at the time of dating is a natural thing. For a statement of my friends who told me never committed serious sexual behavior that is kissing half of respondents $(62.2 \%)$ answered yes, so also in choosing friends who already has a girlfriend sabanyak $48.9 \%$ of respondents answered no and 67 , $8 \%$ of respondents answered no to follow the style of friends in dating.

\section{The Relation of Peer Group with Self-Concept on Sexual Behavior}

Based on a study of 90 students / i adolescent SMA Dharma Bakti Medan known that peer group significantly related to adolescent self-concept with a $p$ value of $0.000(p<0.05)$. Here are the results of analysis.

In bivariate analysis showed that peer group significantly related to adolescent self-concept with a $\mathrm{p}$ value of $0.000(\mathrm{P}<0.05)$. This means that peer group have significant relationship to the self concept of adolescents about sexual behavior.

This study differs from the results Putri (2012) found that peer group influence of strong and weak influence of peer group did not fully affect sexual behavior teenage. Wherein of 54 respondents who peer group intended weak, all respondents $(100 \%)$ of safe sexual behavior [19].

In the peer group teenagers trying to find their self concept. Peer groups provide an environment where teens can socialize with friends his age. But it is dangerous when this peer group tends closed, where each member can not be separated from the group and should follow the value developed by a group leader, attitudes, thoughts, behaviors and lifestyle is a behavior and lifestyle the group. Peer group as an individual interaction on children or teenagers with the level of the same age and involve relatively large familiarity among the group. Relationships peer group on the formation of self-concept of adolescents about sexual behavior is very large, this is because in adolescence, emotional needs of individuals switching from parents to peers. At this time, peers also a source information. Not exception in the formation of self-concept regarding sexual behavior, unfortunately, the information provided by peers tend wrong. Teenage trying to find the concept itself in the peer group. Here he is judged by peers regardless of sanctions adults. Peer groups provide an environment, which is a world where teens can socialize in which the prevailing value is not the value set by adults, but by the same age friends. This is the dangerous location for its peers play a significant role in the lives of teenagers, is no exception in terms of sexuality [8].

Newcomb, Huba, and Hubler (1986) in Hurlock (2003), says that sexual behavior is also influenced positively by peers who are also sexually active. If a teen has friends who are sexually active, the greater the likelihood that adolescents are sexually active to also remember that at that age a teen wants to be accepted by their groups. In adolescence, a tendency to become members of peers (peer group) very kuat. Teenage want friends and become part of the bond between fellow them. Action rule attitude that is recognized and valued in bonding peers regarded as a recognition of the superioritas. Intensive relation and accompanied by a phenomenon called conformity or peer pressure. Peer pressure can mean a condition in which a person adopts the attitude or behavior of others in the group because of the pressure of reality or the impression given by the group which is a factor that greatly affects the formation of adolescent self-concept [20]. When under pressure kolompok bad about sexual behavior, then the self-concept of adolescents about sexual behavior would be bad also, as a result of pressure groups. 
The strong peer group could mean a condition where a person adopts the attitude or behavior of others in the group because of the pressure of reality or the impression given by the group [5]. In mastering the tasks of adolescent development is the establishment of relations a new and more mature with the opposite sex as well as playing the role of gender, adolescents experiencing social pressures either from the environment or from a peer group but are particularly is the concept of self and adolescents on sexual interest and curiosity about sex tend to increase [10].

Describes as the strong peer group in adolescence, then usually it is often considered to be a factor that causes a bad teenage behavior [8]. If the environment supports peer groupremaja to do sex, many teens are very likely to have sex freely. This not only affects the youth in touch with his family, but also affects social life, school and hopes.

The quality of the friendship with peer group will provide feedback to teens about how it should behave and evaluate themselves and others. It is difficult to do at home because you usually older or more young [5]. Being popular kids can help children in prosocial action and create a habit help groups of friends group. Prosocial actions referred to as the ability to solve social problems, positive social behavior and assist them in a relationship of friendship.

Teens are always trying to find the concept itself in the peer group. Peer groups provide an environment, which is a world where teens can socialize in which the prevailing value is not the value set by adults, but by friends of his age. Here lies the dangerous for adolescent mental development, if the value of which is developed in this peer group tend to be closed, in which each member can not be separated from the group and should follow the value developed by the peer group, for example in terms of sexual behavior [8].

Thus, in the formation of adolescent self-concept role of parents is the primary because the family is the smallest in the public sphere. While in the world of education, especially in schools the teacher's role to replace the role of parents and also with their peers (peer group) will complete the juvenile reference in shaping the concept itself [13]. Surely that is expected is a good self-concept especially in terms of behavior sexual. Better upbringing of the family that parents and siblings then from that school teachers and peers can hone adolescent behavior becomes better and impact positively will be able to compete better in world education and the world of work for the future.

\section{V.CONCLUSION}

Peer group have a significantly influence adolescent self-concept with a $\mathrm{p}$ value of 0.001 ( $\mathrm{p}$ $<0.05)$. The self-concept is not innate, but rather the result of learning. Since humans know the environment, since it is also he learned many things about life. Based on the experience of his life, a person will establish the concept itself is based on various factors. Those factors are the shape of the body, disability, clothing, names and nicknames, intelligence intelligence, level of aspiration / aspiration, emotion, type / prestige of the school, social status, economic family, friends, and character / influential person. When various factors that tend to lead to positive feelings (pride, happy), then comes the positive self-concept [9].

Peer group as an individual interactions in children or adolescents with same age level and involve relatively large familiarity among the group.

\section{SUGGESTIONS}

1. The school should instill more discipline to generate the attitudes and behaviors of discipline in students, increase interest in learning habits of students to excel, so avoid the behavior that is incompatible with the norms of society. Party schools should make more effective guidance and counseling in schools where by presenting a counselor competent in their field and mastering the principles, principles, functions and objectives of the guidance and counseling so that students can not only helped in solving the problem, but no longer considers the guidance and counseling as a student -siswa naughty or problematic alone but is a good solve problems of teaching in schools and the students' personal problems themselves. The school also should direct the students in order to give priority to studying and environmentally sensitive peers and has a fixed establishment to escape from the 
behavior of peers that can lead to negative things. Following the positive activities both within the school and outside the school environment and to establish good communication to teachers and parents.

2. For the Department of Education in collaboration with the Department of Health to provide counseling about how best to conceptualize her teens about sexual behavior that is reasonable and likely to be positive.

3. For the next researcher who is interested in studying advised to examine other factors that berhubungandengan peer group of self-concept of sexual behavior such as cultures, socioeconomic, environmental residence, and marital status of parents, so as to obtain a more detailed picture and Detailed on this topic.

\section{REFERENCES}

[1] BKKBN, 2012.Pedoman Management of Adolescent Family Development (BKR). Jakarta.

[2] BKKBN, BPS, Ministry of Health, MEASURE DHS, ICF International. Indonesia Demographic and Health Survey 2012 Adolescent Reproductive Health. Jakarta.

[3] Indonesia Demographic and Health Survey 2012. Jakarta.

[4] Burn, RB 1993. Self Concept; Measurement Theory and Behavioral Development. Jakarta.

[5] Santrock, JW 2003. Adolescence Development Remaja Erlangga.Jakarta

[6] Cynthia, T. 2007. Conformity Group Free Sex And Behavior In Teens. Journal of Psychology Volume 1, No. December 1, 2007.

[7] Ministry of Health, 2010. Module Adolescent Reproductive Health, Jakarta: Ministry of Health. 2008. Guidelines for Adolescent Health Care The Health Clinic, Jakarta: Ministry of Health.

[8] Sarwono, SW 2007. Adolescent Psychology. PT. Bumi Siliwangi Bandung _ 2011. Adolescent Psychology, Revised Edition Moulds Fourteenth, Jakarta: King Grafindo Persada.

[9] Hurlock, EB 1973. Child Development. Volume 2. Sixth Edition, Jakarta: Erland.

[10] Hurlock, EB 2003. Developmental Psychology, An Approach Throughout Range Life. Fifth Edition, Jakarta: Erland.

[11] Soetjiningsih.2009. Teens Ages 15-18 Years Much Sexual Behavior Pranikah.http: //www.ugm.ac.id.diakses Thursday, March 20, 2014

[12] Lubis, LN., 2009. Depression Psychological Review, Publisher Kencana Prenada Media Group. Jakarta._—_ 2013.Psikologi Kespro Women

[13] Ma'mun, Abin Syamsuddin. 2007. Educational Psychology Teaching Module Kit System. Revised Edition. PT. Teens Rosdakarya. Bandung.

[14] Monks, FJ \& Knoers, AMP, Haditono.S.R. 2006. Developmental Psychology: An Introduction In Different Parts (Translation Siti Rahayu Haditomo). Sixteenth mold. Yogyakarta: Gadjah Mada University Press

[15] Notoatmodjo, S. 2010. Education and Health Behavior. First Edition, Jakarta: Rineka Reserved.

[16] Nursal, 2008.Faktor Factors Associated with Sexual Behaviour high school students in the city of Padang, http: //www.jurnalkesmas.com.indeks.php.kesmas. article. View.72\% 61.pdf.diakses: Thursday, March 20, 2014 at 22:30 pm

[17] Pardede, Judith Oktaria Christian. 2008. Self-Concept Street Children Age Youth. Journal of Psychology Volume 1, No. 2, June 2008.
[18] Prasetya, C. 2013. Many Factors Influencing Premarital Sex Teen People. http://www.lensaindonesia.com/2013/02/11/banyak-faktoryang-mempenga-ruhi-seks-pra-nikah-kaum-remaja.html. Thursday, March 20, 2014 at 22:30 pm.

[19] Putri Puspa Utami. 2012. Peer Group Relationship With Teen Sexual Behavior In SMA 3 Jakarta Timur. Essay. Faculty of Nursing Science Program in Nursing Science Regular na Sarja Depok July 2012. University of Indonesia.

[20] Santrock, JW 2003. Teen Edition Kesebelas.Erlangga.Jakarta 